\title{
TRENDS AND PERSPECTIVES OF HOT METHODS FOR RECONDITIONING OF WEAR DETAILS
}

\author{
Iliya Todorov ${ }^{1}$, Mitko Stoyanov², Mitko Nikolov ${ }^{1}$, Vladislav Ivanov ${ }^{1}$ \\ "Angel Kanchev" University of Ruse \\ Studentska 8, 7017 Ruse, Bulgaria, e-mail: itodorov@uni-ruse.bg \\ ${ }^{2}$ Faculty of Technics and Technologies, Trakia University \\ Graf Ignatiev 38, 8602 Yambol, Bulgaria, e-mail: mitko_1166@mail.bg
}

\begin{abstract}
The structure, trends and perspectives in development of hot methods as such used for reconditioning of worn details during the new Millennium are presented in the article as well as trends in production of consumables in industrially developing countries. The structure of welding methods is also shown giving priority to its development until 2020. It can be concluded that in the industrially developed countries by 2020 the share of arc welding will be stabilized at levels of $10-15 \%$ of the total number of methods used for weld overlaying of worn-out components. These figures will be $45-55 \%$ and $7-9 \%$ for gas shielded and submerged arc welding respectively. The welding methods that will be prioritized for the period until 2020 will be gas shielded arc welding, contact, laser beam and hybrid welding.
\end{abstract}

Keywords: Welding, Hot plastic deformation, Metallization.

\section{INTRODUCTION}

The current science and practice uses a quite wide variety of technologies and methods for treatment of worn details from machines used at both - agricultural and automotive industries. Technologies defined as such are welding and overlaying; applying of different coatings; usage of methods based on replacing repair size system; insert of additional details; plastic deformation; thermal treatment and many more. Such variety of methods is still used in different countries although their level of application may vary at different degree [1-13].

Among all methods most widely application is consider to have so-called hot methods which including: welding and overlaying, thermal spraying, hot plastic deformation and others. The aim of the recent paper is to establish the trends in development of those methods as such used for reconditioning of worn details.

\section{METHODS}

According [8] all methods related to welding and overlaying takes about $66-70 \%$ among all other methods for reconditioning as they are divided as follow: $22 \%$ applied for gas-shield welding and overlaying; $12 \%$ for vibrating arc gas-shield welding and overlaying; $12 \%$ for submerged arc overlaying, $10 \%$ electro-contact overlaying, $10 \%$ plasma overlaying, $10-16 \%$ summary for all others as lazer beam overlaying, flux-cored overlaying, slag overlaying, etc. (Figure 1).

The structure of the reconditioning technologies during overall hauling of machines in agricultural industry follow approximately the same trends - around $55 \%$ of all details are being reconditioned by welding and overlaying technologies; around $25-30 \%$ by methods belong to repair size system and additional details; around $14 \%$ by methods using polymers and just $3 \%$ - by methods using galvanic coating application [1].

IRITIE Vol. 6, No. 3, 2018 ISSN 1314-8788 (print), ISSN 1314-8796 (online), doi: 10.15547/artte.2018.03.003 


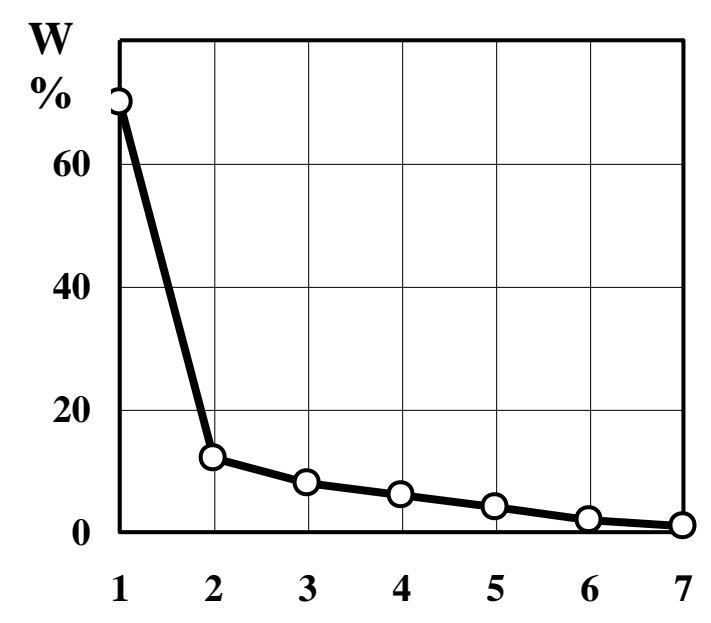

Figure 1. Distribution of methods for worn details reconditioning:

1 - welding and overlaying; 2 - repair size system methods; 3 - galvanic coatings;

4 - polymers usage; 5 - insert of additional details; 6 - plastic deformation;

7 - thermal spraying

On the line between $20^{\text {th }}$ and $21^{\text {st }}$ century welding and weld overlaying are still some of the leading technological process in the world economy. They are used in many industry sectors such as the energy sector, machine building, ship building, bridge construction, automobile industry, transport, agriculture, petrol industry and even in space technologies. Welding is a technology for joining practically all kind of materials such as metals, non-metallic compounds, composite and non-organic materials. For this reason the quality and competitiveness of the welding production is of key importance for the effectiveness of each country's economy.

At the beginning of the third millennium welding and weld overlaying are some of the main technological processes for creating the material foundation of modern civilization. The perspectives for their development are directly related to the production of construction and welding materials. Despite the fact that the use of polymers, light alloys and composite materials in welded constructions is constantly increasing, steels remains the main construction material on a world-wide scale (Figure 2) [10]. The big steel manufacturing countries at the beginning of the $21^{\text {st }}$ century are China, Japan, the USA, Germany and Russia. In 2004 the world production of steel exceeded 1 billion tons. It is expected steel production to reach 1.8 billion tons during the next years with $31 \%$ of it to come from China. According to the world forecasts the consumption of steel will remain stable and it will reach 40 billion tons annually. This amounts to $4-6 \%$ of the total production of steel. It is wellknown that up to $70 \%$ of the world steel production is used for the manufacturing of welded products, constructions and equipment. In many cases welding is the only possible and most effective method of building unassembled joints and resource retaining constructions, approximating the optimal shape. In the future the use of high-tensile steels in welded constructions will continue to increase. The use of aluminum alloys, high-alloy steels, as well as alloys containing effective modifiers (scandium and zirconium) which improve weldability and the mechanic properties of welds will continue to rise. Titanium alloys with good weldability, high strength and corrosion resistance are being developed. 


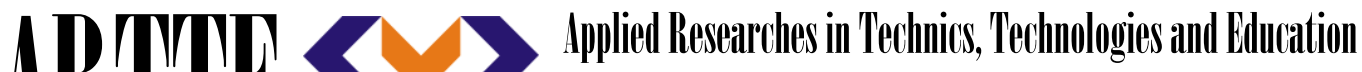 Journal of the Faculty of Technics and Technologies, Trakia University https://sites.google.com/a/trakia-uni.bg/artte/}

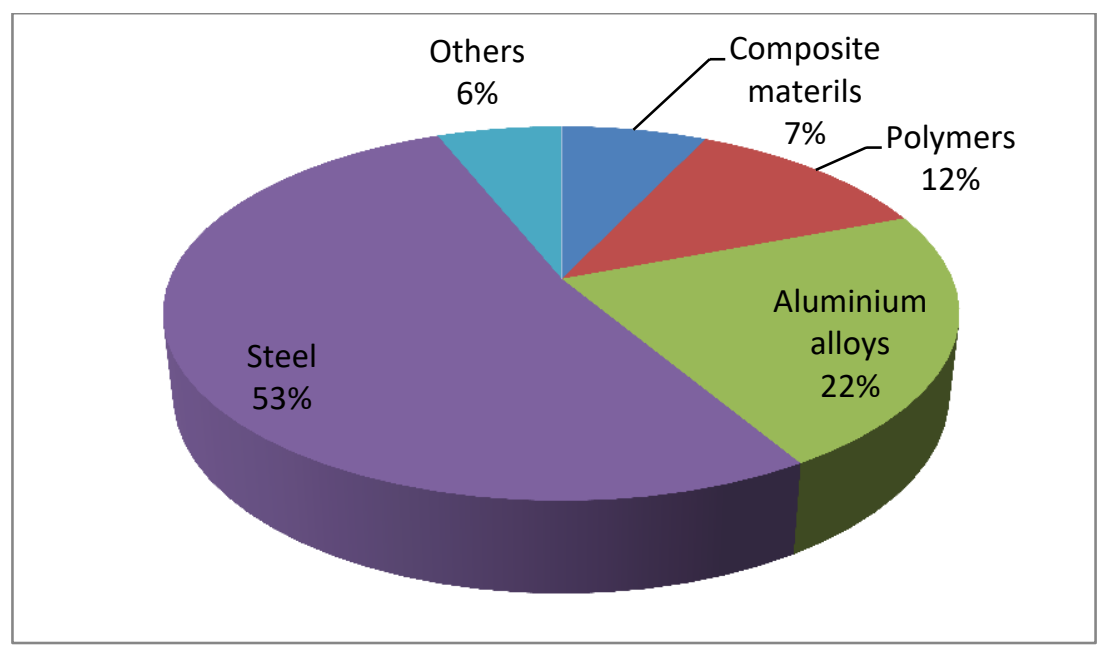

Figure 2. Materials used for welded constructions

At the beginning of the $21^{\text {st }}$ century the world production of welding equipment and materials amounts to 40 billion dollars. $70 \%$ of the incomes are from welding materials while the other $30 \%$ come from the equipment [1]. According to the specialists from the German Welding Association, DVS, the production of electrode materials and equipment in 2004 amounted to 3.6 billion Euros. This is one third of the production in the EU and equals 11 billion Euros. The world production at this time was three times bigger and amounted to 33 billion Euros [2].

There is a sound relationship between the volume of production (consumption) of steel and the use of welding materials employed for arc welding. What is more, for every ton of rolled steel there is 4-6 kg welding materials used. According to data from ESAB [10], in 2000 the weld overlaid metal in the countries of Western Europe was 422 thousand tons and 344 thousand tons in the USA, 236 thousand tons in Japan, 180 thousand tons in China [1] and 152 thousand tons in India [3]. Arc welding continues to be one of the most-widely spread technological options which occupies a share of up to $50 \%$. In fact, the total volume of produced welding materials is for welding with consumable electrodes [11]. In the industrially developed countries during the last 30 years, the weld overlaid manually arc welded metal has reduced three times and is $20-30 \%$ of the total amount of weld overlaid metal [4]. Modern welding and weld overlaying are characterized by high level of mechanization, automation, use of robots and information technologies, computerized management, diagnostics and control. These trends has brought during the last 25 ...30 years a change in the structure of welding materials used for arc welding and weld overlaying in the economically developed countries of the EU, the USA and Japan (Figure 3).

During the period 1986-2005 the amount of produced welding materials ranged from 320-370 million tons. In 1991 it reached a record level of 422 million tons. After that in 1994 the production sharply decreased to reach 303 million tons in 2000. The structure of the arc welding materials world market for the last five years is as follows: electrodes for manual arc welding - 20\%; solid electrode wire - 63\%; tubular-wire electrodes - $9 \%$; submerged arc welding materials - $8 \%[5]$.

The production of electrode wire is the highest in Japan. It increased 3.5 times (from 45 to 160 million tons) for the period 1990 - 2008. For the same period the production of electrodes for manual arc welding went down 8 times, from 400 to 48 million tons. There is a steady trend of reducing the production of electrodes for manual arc welding while the

IRTIII Vol. 6, No. 3, 2018 ISSN 1314-8788 (print), ISSN 1314-8796 (online), doi: 10.15547/artte.2018.03.003 


\section{IRTTE

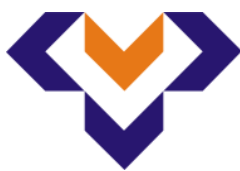 \\ Ipplied Researroches in Technics, Technologies and Bducation \\ Journal of the Faculty of Technics and Technologies, Trakia University https://sites.google.com/a/trakia-uni.bg/artte/}

production of small diameter welding wire electrodes has increased in Japan. During the last years the import of cheap welding wire in Japan from Korea, Taiwan, Thailand, etc. has risen $[2,9,10,11,13]$.

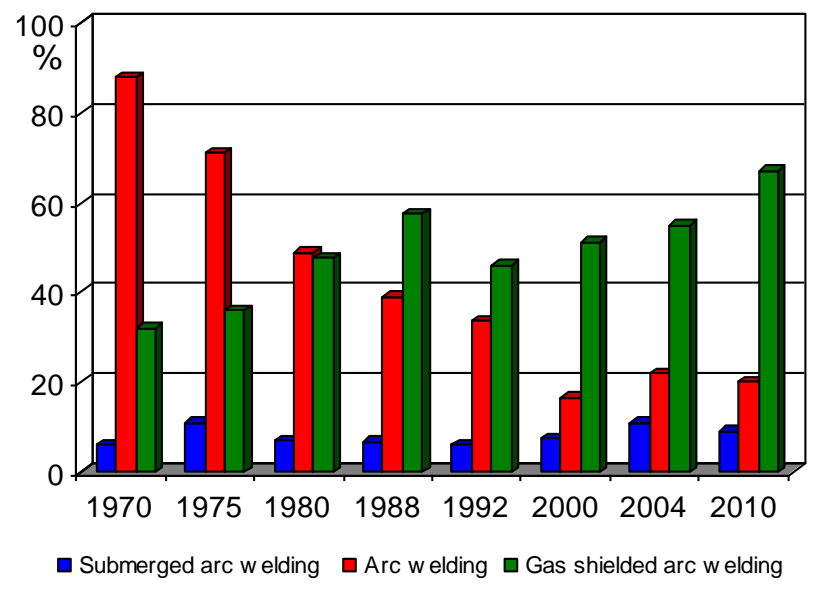

Figure 3. Production of welding materials for arc welding in the industrially developed countries of the EU, the USA and Japan

In Germany, which is the leading economy in the EU, the production of electrode wire increased approximately 2,5 times, i.e. from 30 million t. in 1978 to 76 million t. in 2010, while the production of electrodes for manual arc welding went down more than 5 times ( from 88 to 15 million t. respectively). It should be noted that there was a sharp rise of $41,7 \%$ in the production of electrode materials in 1998 compared to that in 1997. The structure of the produced welding materials in Germany corresponds to that in the EU where there is a drop in the production of electrodes and an increase in the production of electrode wire. During this period there is also an annual growth of $2-3 \%$ in the production of tubular-wire electrodes compared to the production of solid electrode wire [2, 8, 9, 10, 12].

The production of electrode wire in the USA is analogical. From 1980 to 2010 it increased 3 times (from 35 to 105 million t.) while the production of electrodes for manual arc welding decreased by 2,5 times (from 33 to 13 million t.). In the USA there is a continuous trend of increasing the production of electrode wire although until 1988 this growth was marked by certain drops [2, 9, 10, 13].

Submerged welding and weld overlaying for the period 1970-2010 for the three developed countries retained almost constant values being approximately 28 thousand t. for Japan, 10 thousand t. for Germany and 40 thousand t. for the USA.

Based on the mentioned data it is supposed that by 2020 the share of manual arc welding will be stabilized at levels of $10-15 \%$ while figures for the share of gas shielded arc welding will reach $45-55 \%$ of the total number of methods for weld overlaying worn parts. In the developed countries argon based gas mixtures with 8-25 \% of $\mathrm{CO}_{2}$ are widely used for gas shielding. The gas mixture containing argon, carbon dioxide and oxygen are less widely used.

Although there are considerable achievements, worldwide scientists continue to work on the development of new welding and weld overlaying methods. The structure of welding methods which will be a priority and will be further developed during the period $2010-2020$ is shown on Figure 4 [10]. 


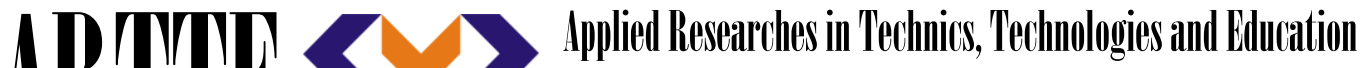 Journal of the Faculty of Technics and Technologies, Trakia University https://sites.google.com/a/trakia-uni.bg/artte/}

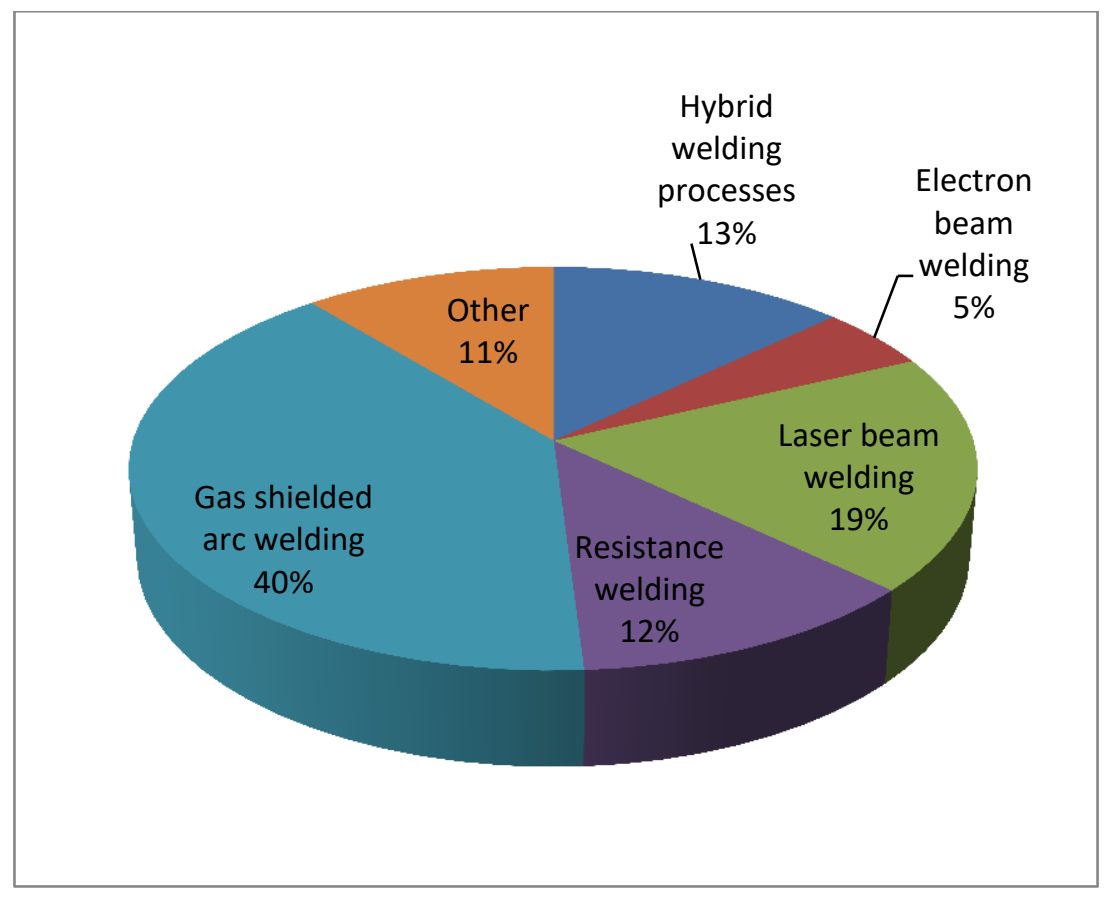

Figure 4. Structure of the welding methods that will be developed with priority in the period 2010-2020

For the period till 2020 the gas shielded arc welding (MIG/MAG, TIG) and cold/contact welding (done by friction/ diffusion) remain the domineering methods. The share of mechanized and automated gas shielded arc welding is increasing. The development of contact welding for this period is related to improving the systems for automated control and constructing powerful electricity supplying equipment. This will solve many technological problems when weld components with high thickness made from different materials. At the same the consumed energy and time needed to complete the welding jobs will be reduced 23 times.

Taking into account the world trends it has to be noted that the scope of applying recoursesaving and preserving technologies will be expanded. It can be assumed that the share of laser beam welding technologies will increase considerably and reach 6-8 \% of all welding. The development of this method is connected with the use of accurate delivery devices. This will allow for better controlling the welding process and will make laser beams more suitable for welding easily - cracked materials or work pieces with spaces between them. The value of welding lasers produced in the EU in 2006 was 3 billion Euros and increased to 5 billion Euros in 2010.

New welding methods called hybrid welding processes (MAG + laser) have been developed in the recent years. These methods combine laser beams with plasma or arc welding in one common welding work surface. The combined effect of the two heat sources on the metal improves the effectiveness of each of them. This leads to an increase in the depth of penetration and the quality of the seam. These hybrid methods are widely used in the automotive industry, ship building, machine engineering and transport. Welding methods such as electron beam welding, diffusion and high-quality welding are of key importance and will continue to develop and improve to meet the requirements of the various industries.

A significant increase of wear-resistance of reconditioned details could be obtained by reinforcement of working surfaces with hard alloys as it is done most often through welding of steel stripe with hard grain alloy applied in advance on it. The size of such grains is between

IRITIE Vol. 6, No. 3, 2018 ISSN 1314-8788 (print), ISSN 1314-8796 (online), doi: 10.15547/artte.2018.03.003 


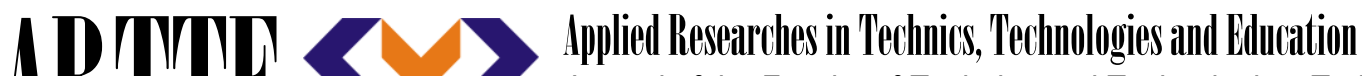 Journal of the Faculty of Technics and Technologies, Trakia University https://sites.google.com/a/trakia-uni.bg/artte/}

0,2-0,6 $\mathrm{mm}$ as the reconditioned surfaces obtaining higher hardness and wear-resistance than such of new details [6,8]. In some of developed countries are being designed and used some special processes as Eutalloy, Rototec and others which allow reconditioning of completely different working surfaces. A possibility for applying of multilayer composition of materials makes them suitable for reconditioning of details used at high thermo-dynamic working conditions. However, they still have a limited application due its higher cost of consumables.

The electric arc thermal spraying is still keeping its significance for reconditioning of worn details although development and usage of many new technologies at recent times. The higher process productivity, wide range of coating thickness $(0,1$ to $6 \mathrm{~mm})$, low consumable cost and possibility of using wires of different materials at the same time as well as possibility of treating of workpieces made of different materials still keeps this method competitive to the newest technologies. It is well used for reconditioning of plain carbon steel as well as alloyed steel and iron, but applying of $\mathrm{Zn}$ or $\mathrm{Al}$ is very good option for achievement of high corrosionresistance of pipes, tubes, tankers, metal constructions, chemical equipment, etc.

Recently, the methods based on hot plastic deformation are taking place in reconditioning of worn details because of their higher productivity, higher durability as well as economy of metal. The compensation of worn metal during hot plastic deformation is obtained through alteration of one or few dimensional values which does not affect the properties of reconditioned details during their exploitation period. Such methods are useful for reconditioning details as gear wheels, bearing bushes, piston pins, chain wheels and others $[8,10]$.

\section{CONCLUSIONS}

There is a wide nomenclature of recent technologies used for reconditioning of worn details in the developing countries as most application of them is given to different methods based on overlaying of working surfaces.

In the industrially developed countries by 2020 the share of arc welding will be stabilized at levels of $10-15 \%$ of the total number of methods used for weld overlaying of worn-out components. These figures will be $45-55 \%$ and $7-9 \%$ for gas shielded and submerged arc welding respectively.

The welding methods that will be prioritized for the period until 2020 will be gas shielded arc welding, contact, laser beam and hybrid welding.

\section{REFERENCES}

[1] Bernardskii, V.N., Makovetskaya O. K. Contemporary condition and forecast for the development of welding production in China. Svarochnoe proizvodstvo. No. 4, 2005, pp. 47-53.

[2] Bernardskii, V.N., Makovetskaya O. K. Modern economy welding production and market of welding equipment. Avtomaticheskay svarka. No. 1, 2007, pp. 44-48.

[3] Gehani, M. L. Welding equipment in India: present state and perspectives. Avtomaticheskay svarka. No. 4, 2006, pp. 32-36.

[4] Gumenyuk, I.V., Ivaskov O.F. Perspectives in the development of welding production. http://svyatik.org/view.php?id=39.

[5] Ilyushenko, A.F., Andreev M.A., Radchenko A.A. Problems and perspectives in the development of welding industry in Belarus.. http://do.gendocs.ru/docs/index16221.html. 


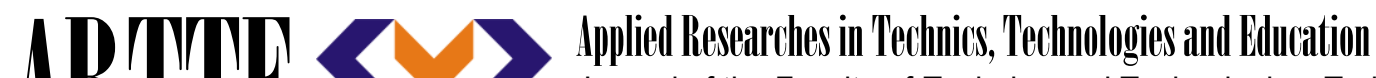 Journal of the Faculty of Technics and Technologies, Trakia University https://sites.google.com/a/trakia-uni.bg/artte/}

[6] Ma Pin A study of the market environment of the welding production technologies on the basis of the world development trends and Chinese experience. http://dtdgma.org.ua/index.php/pro-tekhnikum/novini/8-novini-dtddma/112-perspektivyrazvitiya-svarki-v-xxi-veke.

[7] Mideldorf $\mathrm{K}$. Trends in the development of joining technologies - adding value through welding technologies. 04. 2009, http://www.svarkainfo.ru/rus/lib/blog/?year=200904\&docld $=682$.

[8] Nikolov M., V. Stoyanov. Utilization of resources in maintenance and repair of machines. Ruse, Publishing Center at University of Ruse, 2015, p. 128, ISBN 978-954-712-607-7.

[9] Nikolov M., Todorov T. Aspects of the present state and development of gas shielded arc welding. B: Scientific papers of RU "Angel Kanchev" Vol. 41 Serie 1.1, Ruse, 2004, pp. 138-141.

[10] Perspectives in the development of welding production. http://www.eope.ee/_download/euni_repository/file/3750/1.\%20Keeviskonstruktsioonidele\%20esitata vad\%20nouded..zip/2 .html.

[11] Ruhlin G.V. Development of the industry for producing welding materials in the countries of Western Europe and Japan at the beginning of the century. Avtomaticheskay svarka. No. 5, 2004, pp. 32-38.

[12] Trends and problem in the development of welding industry in Ukraine and Russia. http://dsdmetall.ru/news/2013-07-13/tendentcii-razvitiya-svarochnogo-proizvodstva.

[13] Shalimov M.P. ,Panov V.I. Perspectives in the development of welding in the $21^{\text {st }}$ century. „Svarka Vchera, Sevodnya, Zavtra”, Ekatirinburg, 2006. 